DOI: 10.17707/AgricultForest.61.4.38

\author{
Alenka FIKFAK, \\ Svetislav G. POPOVIĆ, Saja KOSANOVIĆ ${ }^{1}$

\section{SETTLEMENT PATTERNS IN AN AGRARIAN LANDSCAPE - PRINCIPLES OF CLASIFFICATION IN GORIŠKA BRDA, SLOVENIA}

\begin{abstract}
Agrarian settlements represent the essential part of the cultural landscape, which is nowadays transforming because of demographic and functional changes, development of transport networks, the agricultural shift from basic food production to a trade and market-oriented activity, and the inflow of urban programmes and forms into rural areas. The complex relationship between the transformative agrarian landscape, the contemporary socioeconomic component of a rural area, and its pattern and form kept from the past opens a new research interest. The study presented in this paper articulates elements of settlement morphology, and landscape and agricultural strategies found in the predominantly winegrowing area of Goriška brda in west Slovenia. The research deals with the development of a classification system of settlements forms, analyses of statistical and spatial data, and the implementation of various methods of settlement morphology, land use and density level investigation and presentation. The detailed study of 15 selected settlements of Goriška brda and their later comparison show various extremes with regard to the ratio between the number of inhabitants (households) and the agricultural area. The perceived and partially present high pressure on agricultural land may be viewed as a direct indicator of the desire to develop the best agricultural land by building, i.e. for living in a settlement. It is therefore necessary to further develop the interdisciplinary approach to establishing the proper connection between the built area and the agrarian landscape in order to preserve the value of agricultural systems while taking care of cultural, tourist and visual values.
\end{abstract}

Keywords: Settlement pattern, rural area, agrarian landscape, classification, Goriška brda, Slovenia.

\title{
INTRODUCTION
}

In rural areas, settlements become established social units because of the connection between the people and the land, historical factors and sociopolitical relationships (e.g., cultural identity) (Jones, 2010; Roberts, 1996; Robinson,

\footnotetext{
1 Alenka Fikfak, (corresponding author: alenka.fikfak@fa.uni-lj.si), University of Ljubljana, Faculty of Architecture, Zoisova ulica 12, 1000 Ljubljana, SLOVENIA; Svetislav G. Popović, University of Montenegro, Faculty of Architecture, Džordža Vašingtona bb, 81000 Podgorica, MONTENEGRO; Saja Kosanović, University of Priština settled in Kosovska Mitrovica, Faculty of Technical Sciences - Department for Architecture, Kneza Miloša Street No 7, Kosovska Mitrovica. Note: The authors declare that they have no conflicts of interest. Authorship Form signed online.
} 
2003). Types of rural and agrarian settlements and their parts are, without doubt, an essential component of the cultural landscape, with its succession of different civilisations across different historical periods in the form of a continuous cultural sedimentation (Gabrijelčič, Fikfak and Čok, 2005). Application of the GIS tools by overlaying different thematic maps with high resolution orthophotos, combinated with an analysis of spatial structures and causal processes has proved as standard procedure in spatial classification of rural areas in Balkan Region (Curovic and Popovic, 2014; Milos and Bensa, 2014). The localization of rural settlements has always been strongly dependent on natural resource exploitation (Domon, 2011). However, nowadays we witness various processes, such as rural depopulation and population aging, demography changes, functional transformation (the city $=$ a consumption area), which have been, over the last 20 years, paired with problems of discontinuation and abandonment of agriculture due to the lack of production competitiveness in the regions defined as areas with restricted factors for agriculture. Current land development patterns have been strongly influenced by past development patterns, agricultural suitability, transportation, natural amenities, and economic and recreational characteristics (Gude et al., 2006). In parallel, there is a boost in the growth of the urban fabric in rural areas, resulting from the construction and motorway transport corridors. Thus, urban densification along transport corridors and a densely branched network of secondary roads provided short access links to the rural hinterland. This is no longer the destination of users or "Sunday visitors" looking for "a memory of times gone by", but an ideal scheme of living on one's own land, in one's own house, away from the urban noise and stress of the contemporary working environment. Easily accessible areas in terms of transport with a shortened travel time distance from the main centres are, on a European scale, becoming the priority locations for housing construction and for people in active liberal professions, and others. Through the aforementioned structural changes, distinctly urban programmes and forms of built patterns also move to rural areas, as agriculture becomes a trade and market-oriented activity, and no longer an activity directed only towards food production. On the other hand, it may be argued that the "agrarian landscape is always the result of the layering and overlaying of humanity's interventions in the past” (Tempesta, 2010, 259).

Nowadays, with many ongoing discussions about the various types of interventions, utilisation and protection of agricultural land such as organic farming, biodynamic farming, integrated processing (i.e. sustainable types of farming), the EU Common agricultural policy (CAP) attaches great importance to environmental issues concerning climate change, soil depletion, water and air quality and loss of biodiversity. Since 2000, CAP (European Commission, 2012, 3 ) has paid more attention to the economic, social, and cultural development of European rural areas. "Today's generation of farmers combines the roles of farmer, steward of the countryside and entrepreneur. The reforms made farmers more market-oriented. Some of them process food on the farm and sell it locally, 
boosting the rural economy. Farmers support their communities through rural tourism, new business creation and cultural activities” (European Commission, 2012, 14).

Seemingly simpler than urban ones, the rural patterns are nowadays becoming growingly complex. The landscape tends to undergo modification over time with the evolution of the social organisation of the group and its relationships with the territory (Antrop, 2005). In this sense, we see a contemporary hamlet as a form of the past, upgraded with new content in the context of the wider world. The complexity of these patterns is hidden in the relationship to surrounding land: most people are active in two conflicting poles - the morning intellectual activity and the afternoon active work, i.e. work on land. The relationship of the population's activities is not attached to a pattern and its form, because the pattern and its form originate from the past when the design concerned the activities related to permanent settlement or the manifestation of the pattern in space (Fikfak, 2008, 58). In addition, many questions arise not only about the system of classification itself, but about pursuing the essence of rural settlements (Roberts, 1996, 96). What is happening in rural settlements, and what will their future look like?

\section{Study area}

\section{MATERIAL AND METHODS}

The investigated area of Goriška brda, administratively defined as the Municipality of Brda, is located in west Slovenia (Figure 1). It is a part of the North Primorska region (the Goriška Statistical region; it covers 13 municipalities, extending across nearly $2325 \mathrm{~km}^{2}$ ).

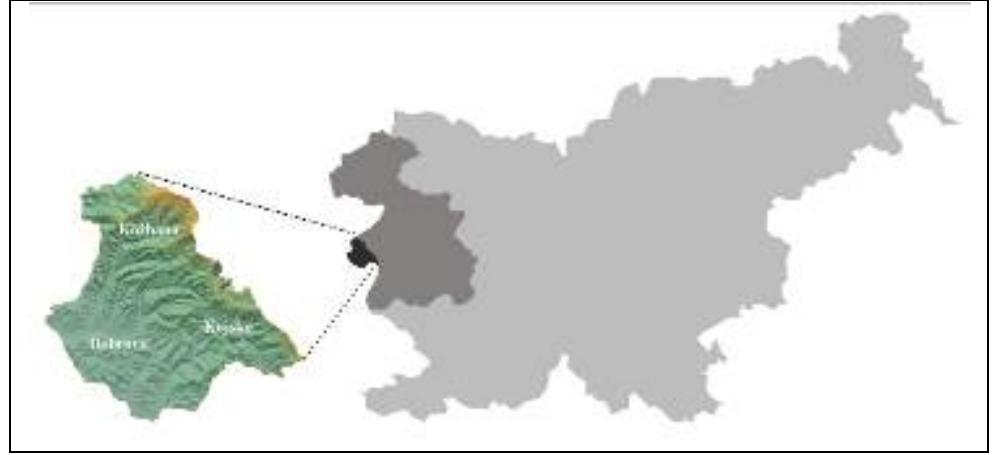

Figure 1. The study area (right: the position of the study area in Slovenia; left: the Municipality of Brda, digital relief model with 3 main centres indicated: Dobrovo [municipality center], Kojsko, Kožbana).

The Goriška region has 118374 inhabitants (on 1 January 2014; 89426 inhabitants who live in rural areas), with 30195 ha of total utilised agricultural areas (on 31 December 2013), and with 5790 agricultural holdings with a total 
area of 63090 ha (of which 36717 ha utilised agricultural areas; 2010)․․ "In 2010, permanent crops in Slovenia occupied 1.3\% of the total territory, and 5.6\% of agricultural land used by agricultural holdings. According to the proportion of permanent crops in relation to the overall municipality area, the Municipality of Brda particularly stood out in 2010 (31\%)” (Kutin Slatnar et al., 2010, 25).

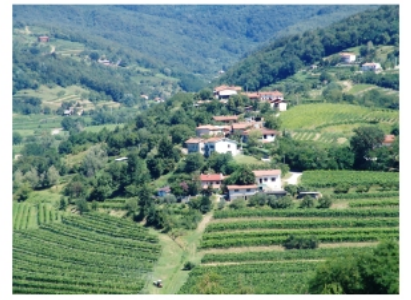

Brdice pri Neblem_ Lower Brda.

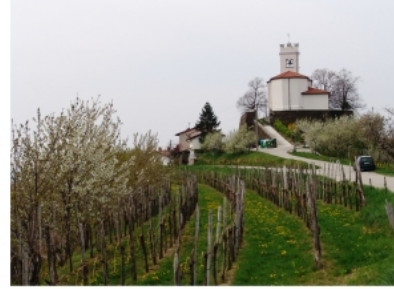

Church as a dominant_Vedrijan.

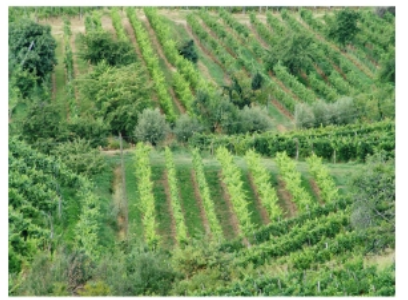

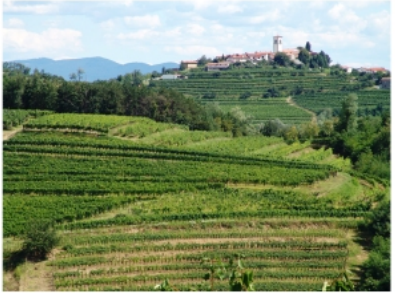

Medana_Lower Brda.

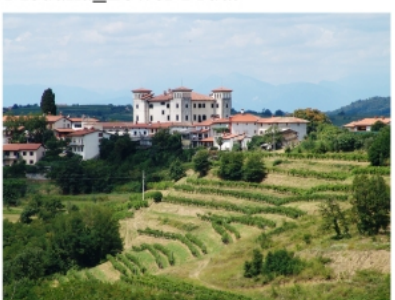

Castle as a dominant_Dobrovo.

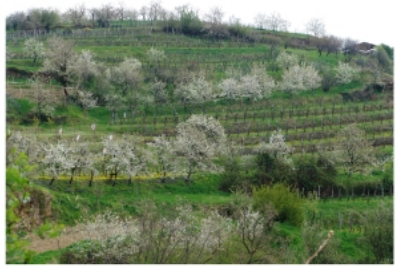

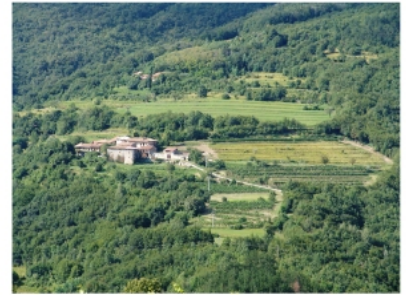

Slapnik_Upper Brda.

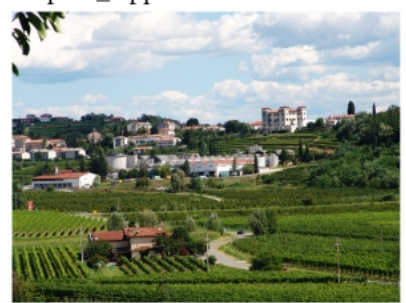

Winery as a dominant_Dobrovo.

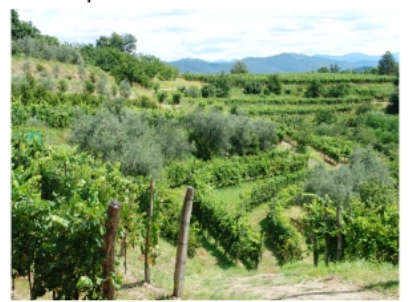

Agricultural patterns_ mixure of vineyards, cultural teraces, fruit trees, olive trees,...

Figure 2. The Goriška brda landscape

Goriška brda (area of $72 \mathrm{~km}^{2}$ ) is an independent, geographically and spatially completed unit with 5662 residents (2015); in 2012 there were, on average, 101 residents per $\mathrm{km}^{2}$. The average altitude of Goriška brda is $232.9 \mathrm{~m}$ (Kladnik, 1998). Goriška brda is a border landscape in three respects: it is a state border, a national border, and lies at the contact between hills and lowlands. The varied morphology of its landscapes is oriented from the south with the plain area, which starts in the Friulian Plain, across the undulating hilly areas of Brda to the mountains in the north, manifested as diversity with three central lines of ridges. Vrišer (1956) reported about 14 different ridge levels. Soil erosion is a major problem, particularly due to deforestation. The area is characterised by soft flysch indented with streams, which created a distinct image of hills with northsouth stretching ridges and with shorter transversal ridges (Žnidar, 2015, 14).

\footnotetext{
${ }^{2}$ Source of all statistical data: SURS (Statistical Office of the Republic of Slovenia)
} 
Ever since Goriška brda has been first settled, its land has been continuously used for winegrowing on cultivated terraces. All other crops (olives, potatoes, various cereals, soya, cherries, peaches, plums, etc.) came and went, and the ways of cultivation changed (in relation to mechanisation and crop rotation), but the vines were always present and dominated the region's image.

\section{Settlements history}

Archaeological finds bear witness to the original settlement of Goriška brda, i.e. a high-altitude fortified settlement on the hill of Sv. Marija na Jezeru at Golo Brdo, which, based on comparison to similar settlements in Vipavska dolina and Furlanija, dates back to the mid-2nd millennium BC, but more probably to the Bronze Age (Svoljšak, 1999). The terrain diversity and the geomorphological structure (a ridge appropriate for stable construction, proximity of fertile land) affected the emergence of settlements, their spatial setting, layout, and organisation of its parts - homesteads, etc. Among the most important factors influencing the organisation of the settlement structure were: its leeward position, appropriate insolation, good drinking water supply and fertile land for cultivation. The distribution of settlement structure in Goriška brda today reflects the settlement and organisation of space that was in the past based on colonisation. According to Kos (1923), all major settlements retained their original form. In terms of layout, these are mostly nucleated villages situated on ridges, usually clustered together in a small area in a state of proper Mediterranean disorder, following a "natural geometry". However, Brda does not have a single uniform landscape image. The settlement patterns change in the south-north direction and remain dispersed in the landscape, but compact within each settlement pattern (Fikfak, 2008). Settlements become smaller to the north and do not "spill across" the entire ridges, because there is much less room for expansion.

\section{Agrarian landscape}

The typology of cropland distribution characteristic for Goriška brda is the following (Kladnik in Fridl et al., 1998, 292): “The agricultural landscape with fields in proper or original irregularly shaped parcels is dispersed, while its parts are mixed together without order. Land plots are mostly irregularly shaped. It mostly consists of original hamlets and nucleated villages.” The Goriška brda image was most significantly changed in the Reka River plain, affected by land reclamation, which completely changed the structural image of space and land use. The once diverse and fragmented appearance of the plain changed into a uniform, continuous shape (uniform parcels), mostly intended for vineyards and peach trees. Nowadays, Goriška brda is increasingly becoming a vineyard region, while fruit production is in decline, even though the value of tradition is increasingly gaining importance (return of various crops, e.g. olive trees, and fruit production customs). Vines cover 1950 ha, i.e. 70 percent of all agricultural land in Brda (source of data: Srebrnič, 2009). The fine structure of agricultural land use (related to operation of individual farms) is not only a consequence of the current administrative and governance practice and plot divisions 
(inheritance, agrarian reform), but rather it corresponds to the diversity of the terrain and crop rotations. There is a growing number of cases when wine growers save quality products from particularly favourable locations as vintage wines, by assigning the characteristics of the area. When studying the agrarian landscape of Goriška brda we wonder how these areas managed to preserve the image of an agriculturally developed cultivated landscape. In a landscape where the self-sufficiency and self-organisation of country people was dominated by the need to survive, the decision about the multifunctionality of agriculture was a question of needs. In the past, this only referred to the diversity of introducing various crops and their succession even on the same land (e.g. vineyards interplanted with potatoes, or olives and figs grown on slopes). Nowadays, the multifunctionality captures the overall operation of the agricultural complex and its integration with the settlement. By incorporating cultural functions such as visual quality, recreation and historic preservation, multifunctional landscapes can contribute to preservation of landscape history and public enjoyment of the rural environment (Carey et al., 2003). Unlike the more ambiguous term "sustainability", the concept of multifunctionality suggests an opportunity to develop specific goals or targets for ecological, production and cultural functions to improve landscape performance (Taylor Lovell et al., 2010, 330). Goriška brda seasonally change their "landscape performance", while they are referred to as the land of ravishing moments or the country of white churches on top of hills, the country of castles, the country of beautiful views, the country of artists, the Kožbana corner - treasury of natural heritage of Brda, etc.

\section{Settlement mapping and analysis}

Settlement systems are highly diverse and change constantly. This happens both within the system itself as well as in relation to adjacent systems. This volatility originates in the "non-permanence" of settlement patterns, which are continuously updated, transformed, broken, emptied, etc. This study articulates elements of settlements morphology, and landscape and agricultural strategies found in 15 case study settlements of Goriška brda (Figure 3); every settlement was studied in detail (Figures 4, 5 and 6a, 6b, 6c).

The study implements the following research methods of settlement morphological analysis in relation to agricultural land:

a. Compilation of historical maps (a unique inventory of urban history and morphological evolution of Goriška brda): Slovenia on a military survey map 1763-1787 (1804) - 3rd volume; Josephinische Landesaufnahme 1763-1787 (1804) für das Gebiet der Republik Slowenien - Karten - 3. Band; sections 156 and 181. Basic scale of the survey is 1:28 880; the Franziscean Cadastre, 18191950 (source: Archivio di Stato di Trieste); Topographical map of the area (Italian map) made around 1930. Scale of 1:25 000; Digital municipality plan (DKN), 2014 and orthophoto maps, 2014; scale of 1:5 000.

b. CAD drawing and planar/axonometric representation via digital simulations and graphic-based computer programming (i.e.: CAD, 3D Max). 

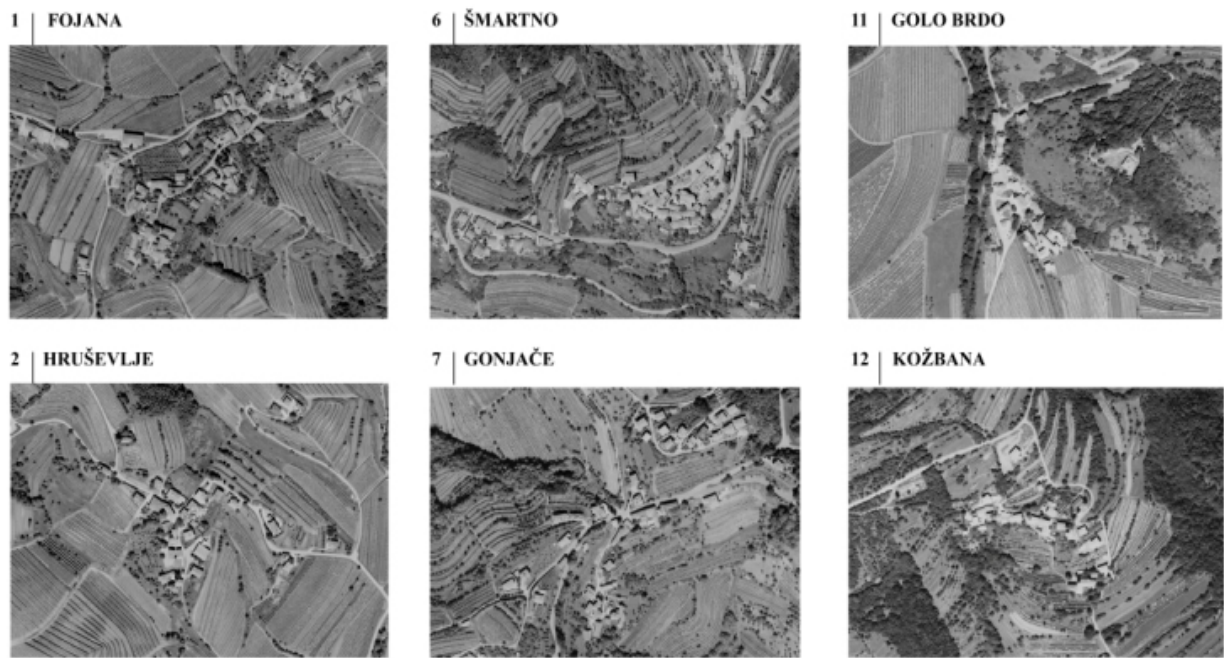

12 KOŽBaNA
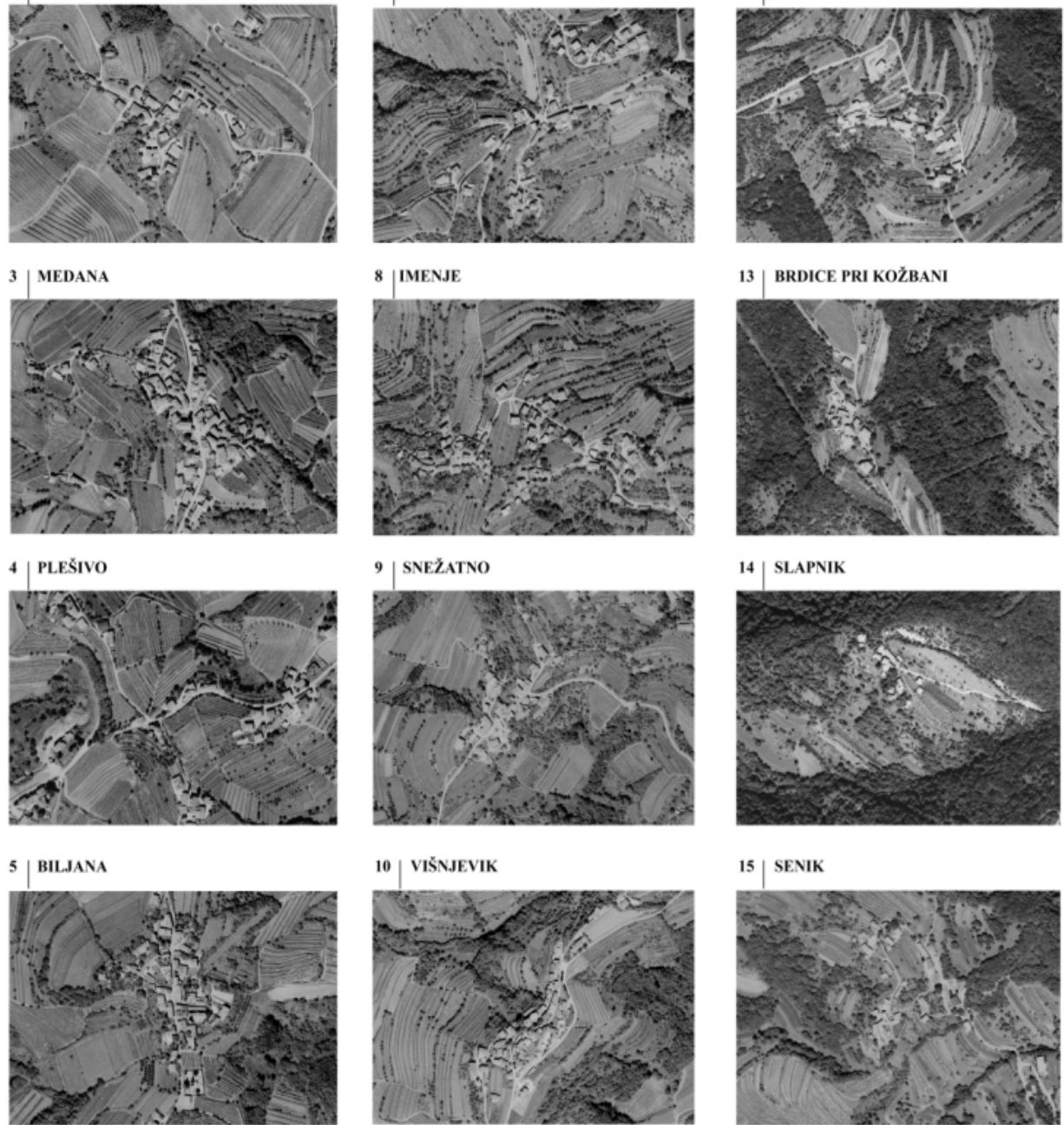

10 VIŠNJEVIK

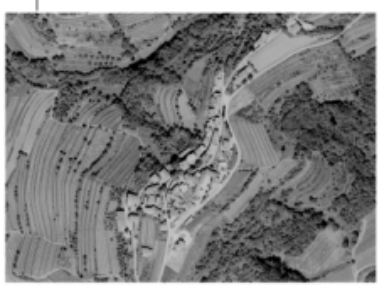

15 SENIK

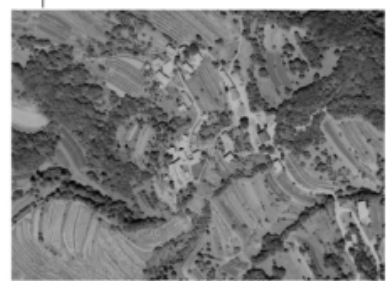

$\overbrace{\text { Metric bar }}^{50} \underbrace{100}_{\text {meters }} \bigcup^{200} \mathrm{~N}$

Figure 3. Settlement mapping, selected settlements in Goriška brda. 

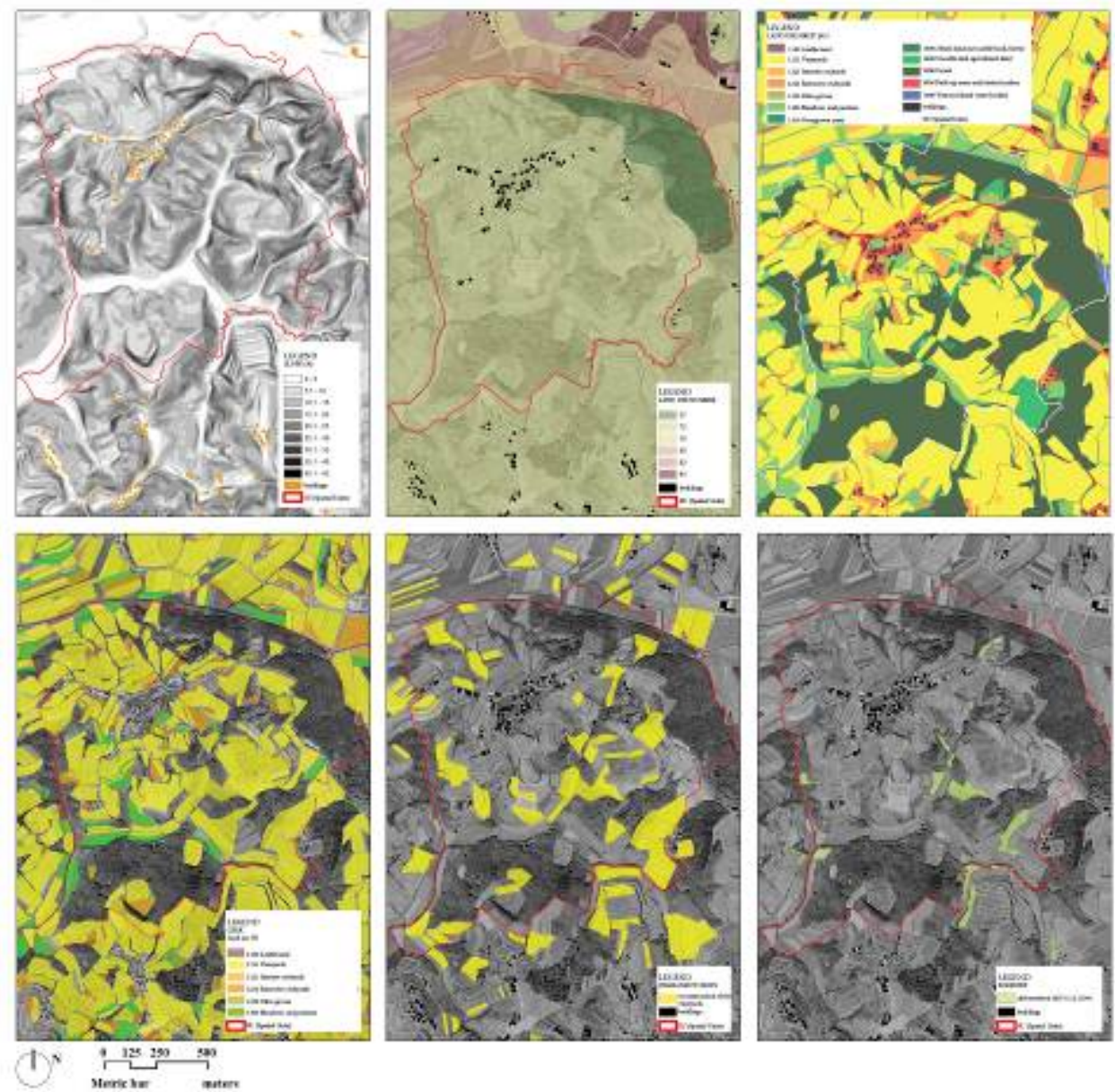

Figure 4. Presentation of a detailed spatial analysis - the case of settlement Fojana.
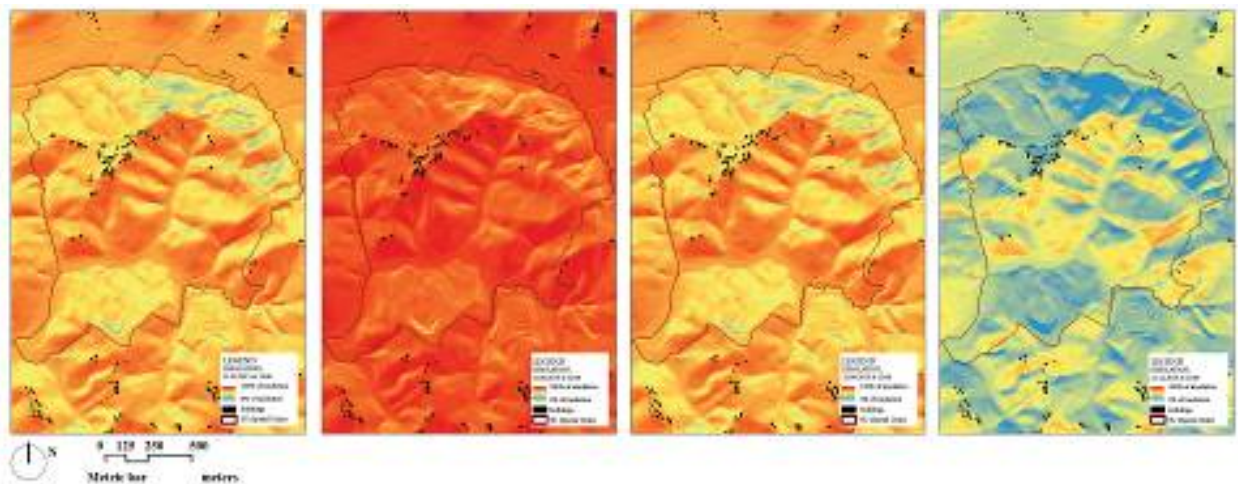

Figure 5. Spatial analysis - insolation (from left to right: 21 March 2015, 21 June 2015, 21 Sept. 2015, 21 Dec. 2014), the case of settlement Fojana. 
d. Land analyses and complex digital simulations of land use, such as: Esri, DigitalGlobe, GeoEye, Getmapping, Aerogrid, GIS User Community. Global Land Survey (GLS) GLS permits the study of landscape change including land use change, deforestation/reforestation, urbanisation, disaster assessment and water level change.

e. Analysis on the level of regional development of urban sprawl and land use: insolation, terrain gradient, altitude, permanent crops, deforestation (Graphical Agricultural Unit of a Farm Holding, GERK) (source: Atlas okolja [Agencija RS za okolje], Ministry of Agriculture, Forestry and Food RS [MKGP RS], Ministry of Environment and Spatial Planning, The Surveying and Mapping Authority of RS [GURS], Corine 2000 and Natura 2000 data).

f. For overview and analysis of statistical data - Data Portal of the Statistical Office of the RS - SI-Stat.

g. For determining the level of density between nucleation and dispersion, a quantitative or statistical technique was used, i.e. the "Nearest Neighbour Analysis“" (Waugh, 1990, 340-42). Such an overview of spatial data shows us the direction that a certain patterns takes: densification, dispersion or uniformity of a pattern. The morphology of the built geometry was done on the level of each settlement and as a combination of the relations between neighbour structures (settlements, farms, hamlets, etc.).

The study presented in this paper was not focused on the tools for designing the landscape multifunctionality approach but on research as to what was the traditional process of connections between the built area of settlements with the agricultural landscape, and how this dialogue persists in today's development of the culture and identity in the contemporary organization of settlements.

The classification system of settlement forms (Table 1, Figures 6a, 6b, 6c) is based on the characteristics, meanings and impacts of the basic living unit to the surrounding agricultural landscape (Figure 4), and among the individual settlement patterns within the SUs (Spatial Units) of a settlement.

Table 1. Settlement patterns classification.

\begin{tabular}{|c|c|c|c|c|}
\hline PATTERN & & FORM & LAYOUT & $\begin{array}{l}\text { DEVELOPMENT } \\
\text { STAGE }\end{array}$ \\
\hline isolated farmstead & $\mathbf{F}$ & linear (line, roadside) L & regular I & nucleated \\
\hline hamlet & $\mathbf{H}$ & circle (cluster) & irregular IR & dispersion \\
\hline village & $\mathrm{v}$ & grid* $^{*}$ & & diffusion \\
\hline settlement & $\mathrm{s}$ & & & suburbanisation $\mathrm{S}$ \\
\hline central settlement & CS & & & urbanisation \\
\hline
\end{tabular}

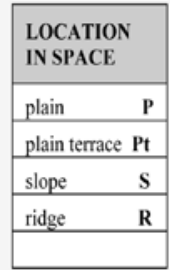

\begin{tabular}{|lr|}
\hline $\begin{array}{lr}\text { AGRARIAN } \\
\text { LANDSCAPE }\end{array}$ \\
\hline vineyards & $\mathrm{V}$ \\
\hline orchards & O \\
\hline meadows & $\mathrm{M}$ \\
\hline forest & $\mathrm{F}$ \\
\hline deforestation/overgrowth & $\mathrm{d} / \mathbf{0}$ \\
\hline
\end{tabular}




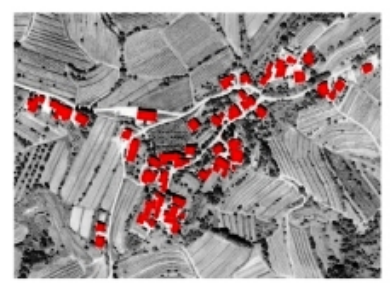

45'59'52.81"-N 13'30'24.42"E Amw: 1.49 km', Elenution: $154.6 \mathrm{~m}$

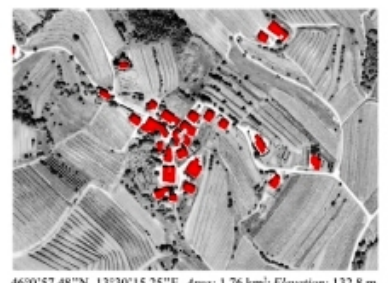

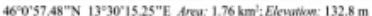
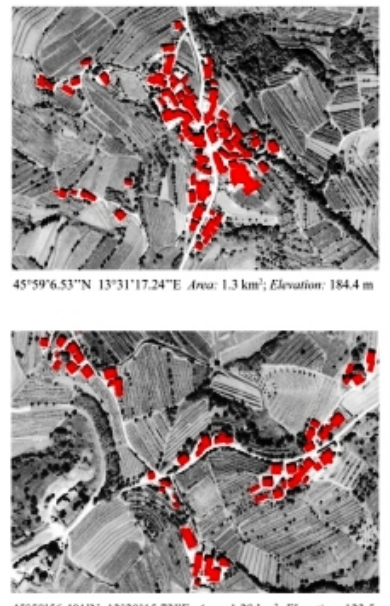

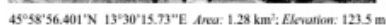

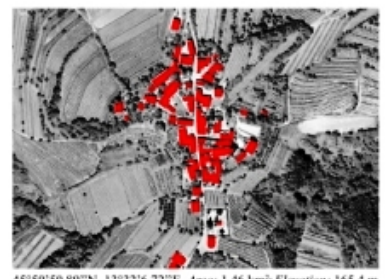

1 FOJANA_Lower Brda_V_L_IR_Di_R_V

Characteristics: the first agricultural cooperative in Brda, established in 1922; composer and conductor Rado Simoniti; two churches: Church of Holy Spirit on the Lake and St. Florian's church; a countryside mansion,

Settlement bypology_patterns: linear layout of an irregularly-shaped village, situated on a ridge, it includes three nucleated subunits: one by St. Florian's church and two clustered areas,

Land use: prevalence of permanent vineyards, partially deciduous forest (approx. $25 \%$ TSA); changing of the forest into cultivated terraces (approx. 5\% TSA),

Agriculture: cultivated terraces, fragmented land plots - vines; forest; crops as home gardening: persimmons, cherries, apricots, and peaches.

\section{HRUŠEVLJE_Lower Brda_V_L_IR_Di_S_V ${ }^{4}$}

Characteristics: Church of St. Margaret; at Peternel the site of a fire set on 22 May 1943 (9 victims from the village),

Settlement typology_patterns: linear layout of an irregularly-shaped village, which is further developed along the road line, it consists of a nucleated core with many hamlets - Borśt, Cisto, Jama, Celo,

Land use: permanent vineyards, deciduous forest (approx. 50\% TSA ${ }^{3}$ ); mixed agricultural areas,

Agriculture: cultivated terraces, fragmented land plots - vines; forest as large continuous areas; to a lesser extent additional crops as home gardening.

\section{MEDANA Lower Brda V C IR_N_R V}

Characteristics: village with a lively cultural pulse; market area and the Church of St. Mary; it boasts the largest concentration of wineries in Brda; poet Alojz Gradnik; the MMM Art Artists' Colony; Days of Poetry and Wine,

Settlement typology patterns: regular shape of centric (nucleated) layout of the village, situated on a ridge, discontinued with the line along the communication, two hamlets,

Land use: permanent vineyards; individual olive groves and additional crops as home gardening: persimmons, cherries, apricots, peaches; forest approx. $10 \% \mathrm{TSA}^{3}$

Agriculture: cultivated terraces, fragmented land plots - vines; additional crops as home gardening intertwine with the built fabric.

\section{4 | PLEŠivo_Lower Brda_H_L_IR_Dr_R_V}

Characteristics: hamlet of Jordano, formerly the property of the Jesuits; after the abolition of the Jesuit Order, the estate was bought by the Catterini family and let for use to the Dominicans,

Settlement typology patterns: a dispersed, ridgetop settlement, composed of linear and centric clustered subunits of many hamlets and isolated farmsteads,

Land use: permanent vineyards; individual olive groves and additional crops as home gardening: persimmons, cherries, apricots, peaches; forest approx. $10 \% \mathrm{TSA}^{3}$,

Agriculture: cultivated terraces, fragmented land plots - vines; additional crops as home gardening intertwine with the built fabric.

5 | BILJANA_Lower Brda_V_C_IR_N_R_V

Characteristics: Church of St. Michael; the countryside mansion from the 13th century with a courtyard, embrasures, and portals; famous for the Fourth Biljana Meeting in 1869

Settlement bpology patterns: the original linear layout of the village situated on a ridge is expanded and complemented along the road, which is inconsistent with the continuous built-up settlement pattem Land use: permanent vineyards and mixed agricultural land; forest (approx. 30\% TSA $\mathrm{TA}^{3}$ ); additional crops as home gardening: olive groves, persimmons, cherries, apricots, peaches; changing of the forest into cultivated terraces (approx. $5 \%$ of $\mathrm{TSA}^{3}$ )

Agriculture: cultivated terraces, fragmented land plots - vines; additional crops as home gardening intertwine with the built fabric

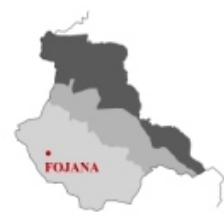

FOJANA, First necond: 1188' Popwlation: 149 inhahitants (2015) Cadastral Municipality: 2285 Biljan

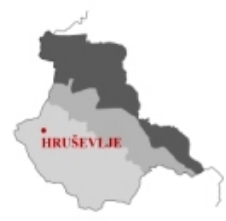

HRUŚEVLE, First necovd: 1319 Population: 119 inhabitants (2015) Cadastral Municipality= 2284 Neblo

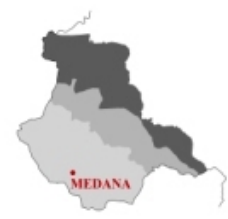

MEDANA, First neond: 610 Population: 238 inhabitants (2015) Cadastral Municipality: 2286 Medan

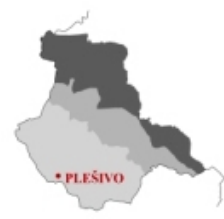

PLEŠ́vo, Fìst recont: data not available. Population: 224 inhabitants (2015)? Codastral Municipality: 2286 Medan

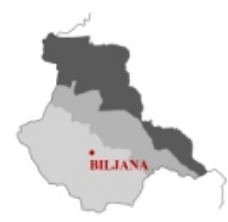

BILJANA, Finst woond: 1205' Population: 154 inhabitants (2015) Cadastral Municipality: 2285 Biljana

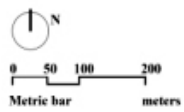

' Kos, F., 1923. Goriska brda v srednjem veku. In: Stres, P. (ed.) et al., 1999. Briski zbornik. Dobrovo: občina Brda, pp. 32-73. ${ }^{2}$ Statistical Office of the Republic of Slovenia, Ljubljana, SI-STAT, data from I January 2015. Accessed on 10 Sept. 2015 http://pxweb.stat.si/pxweb/Dialog/varval.asp?ma-05C5002S\&ti-\&path=../Database/Dem soc/05 prebivalstvo/10 stevilo preb/25 05C50 prebivalstvo naselja/\&lang $=2$

${ }^{3}$ op. TSA - the total settlement area.

'Settlement patterns classification: pattern_form_layout_development stage_location in space_agrarian landscape.

Figure 6a. Settlement mapping. Presentation of settlements of the Lower Brda (5 out of 18 in the area). 


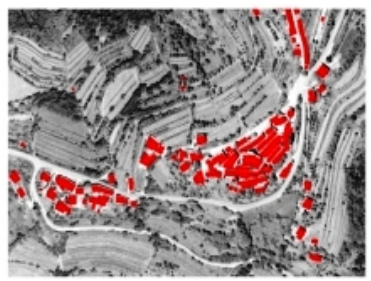

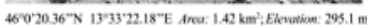
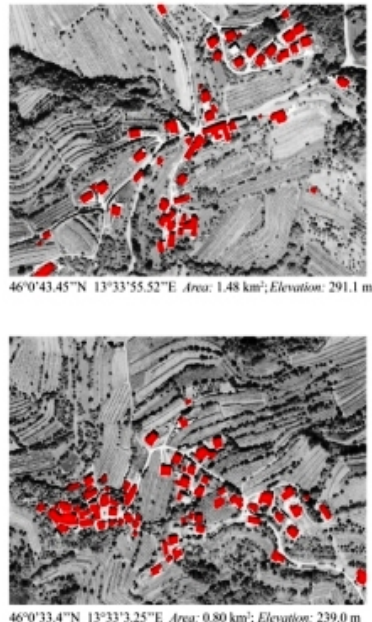

8 | IMENJE_Central Brda_V_C_IR_Di_R_V*

6 |ŠMARTNO_Central Brda_S_C_IR_Di_R_V ${ }^{4}$

Characteristics: built on Roman foundations, a fortification on the strategic Venetian-Austrian border; architectural gem, cultural monument, strategic defence point, Church of St. Martin, a renovated settlement; House of Culture, Briska hisa ("Brdo House"), a wide range of events, Settlement typology_patterns: the central part of the settlement kept its original shape of a fortification (nucleated); expansion outward along the communication line,

Land use: permanent vineyards and mixed agricultural land; fores (approx. 35\% TSA'); additional crops: olive groves, cherries, apricots: changing of the forest into cultivated terraces (approx. $5 \%$ of TSA ${ }^{3}$ ), Agriculture: cultivated terraces, fragmented land plots - vines; additional crops as home gardening and part of cultivated terraces.

\section{7 | GON.JAČE_Central Brda_H_L_IR_Df_R_V}

Characteristics: a memorial to 315 victims of WW2 by sculpto Janez Boljka; a $23 \mathrm{~m}$ high watchtower by architect Marko Ślajmer, Settlement typology_patterns: linear layout of the settlement along the communication line, composed of subunits of hamlets and individual structures,

Land use: permanent vineyards and deciduous forest (approx. $40 \%$ TSA'); additional crops: olive groves, cherries, apricots; changing of the forest into cultivated terraces (approx. 10\% of TSA'), Agriculture: cultivated terraces, fragmented land plots - vines and other crops as part of cultivated terraces; forest as a continuous area.

Characteristics: no significant historical or cultural features, in the shadow of the neighbouring Šmartno,

Settlement typology_patterns: original linear layout of the settlemen is evenly supplemented by the recent linear layout (expansion), but the steep terrain leaves no room for further expansion,

Land use: permanent vineyards and deciduous forest (approx. 35\% TSA'); additional crops: olive groves, cherries, apricots, peaches. Agriculture: cultivated terraces, fragmented land plots - vines; other crops as part of home gardening and cultivated terraces; forest as a continuous area.

\section{9 | SNEŽATNO_Central Brda_V_L_IR_Di_R_V}

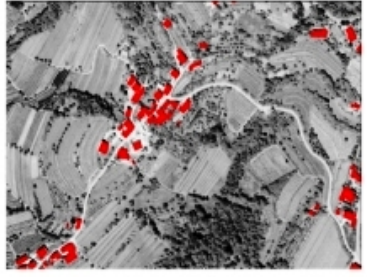

Characteristics: no significant historical or cultural features, in Slovenia famous for the Kmetija reality show,

Settlement typology patterns: the linear layout of the settlement remains in the shape of a hamlet that could not develop further due to the steep terrain.

Land use: permanent vineyards; smaller proportion of mixed agricul tural land use and forest (approx. 10\% TSA $\mathrm{TA}^{3}$ ); additional crops: olive groves, cherries, apricots,

Agriculture: most of TSA is comprised of cultivated terraces - SW direction of hilltop terrain, fragmented land plots - vines and other crops as part of cultivated terraces.

\section{0 | VIŠNJEVIK_Central Brda_V_C_IR_N_R_V}

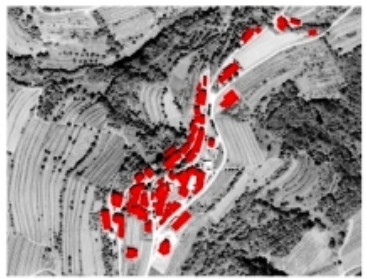

Characteristics: Rittersberg, the oldest castle in Brda-remnants of this castle no longer exist; the birthplace of Rebula, which was first mentioned here as early as 1336; Rebula and Olive Oil Festival, Settlement typology patterns: linear layout of the settlement along the communication line, composed of subunits of hamlets and individual structures,

Land use: permanent vineyards and deciduous forest (approx. $40 \%$ TSA ${ }^{3}$ ); additional crops: olive groves, cherries, apricots, peaches, Agriculture: cultivated terraces, fragmented land plots - vines and olive groves as part of cultivated terraces; other crops as part of home gardening; forest as a continuous area.

I Kos, F., 1923, Goriška brda y srednjem veku. In: Stres, P. (ed.) et al., 1999. Briśki zbornik. Dobrovo: obXina Brda, pp. $32-73$. ${ }^{2}$ Statistical Office of the Republic of Slovenia, Ljubljana, SI-STAT, data from 1 January 2015. Accessed on 10 Sept. 2015 http:/pxweb.stat.si/pxweb/Dialog/varval.asp?ma=05C5002S\&ti=\&path=./Database/Dem_soc/05_prebivalstvo/10_stevilo_ preb/25_05C50_prebivalstvo_naselja/\&lang $=2$

${ }^{3} \mathrm{op}$. TSA - the total settlement area.

${ }^{4}$ Settlement patterns classification: pattern_form_layout_development stage_location in space agrarian landscape.

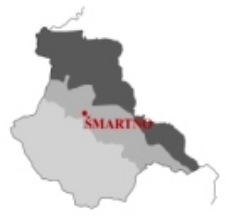

SMARTNO, First reount: 1317

Population: 210 inhabitants $(2015)^{2}$

Cadastral Muricipality: 2281 Ŝmartn

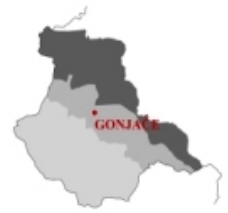

GONACE, Finst mcont: data not available Population: 166 inhabitants (2015) Cadastral Muricipolith: 2281 Śmartn

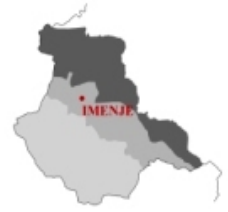

IMENE., First recourl: data not available. Population: 22 inhabitants (2015) Cadastral Municipaliny: 2281 Smartno

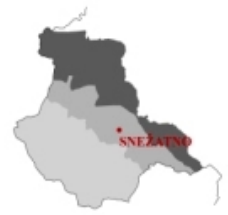

SNEŽATNO Fîst recont. 1449: Population: 83 inhabitants (2015) Cadastral Manicipality: 2290 Kojsko

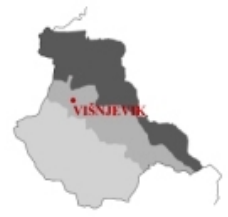

VIŠVIEVIK, Firss necont: 1258 Population: 145 inhabitants (2015) Cadestral Manicipality: 2283 Visnjevil

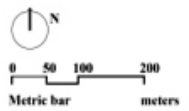
out of 14 in the area). 


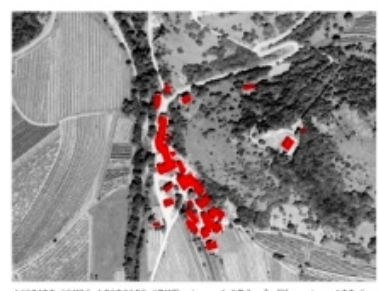

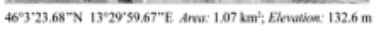

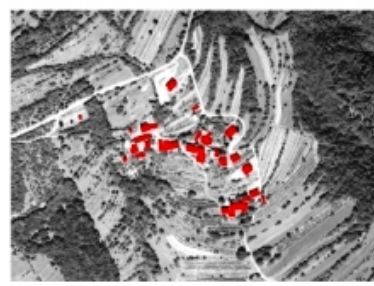

46.2'36.87"N 13931'51.65"E Amx: 0.81 km'; Elevatian: $295.7 \mathrm{~m}$

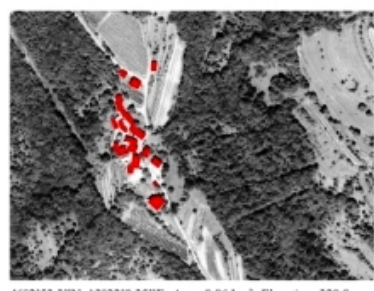

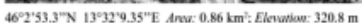

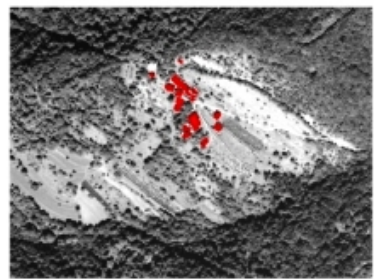

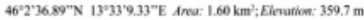

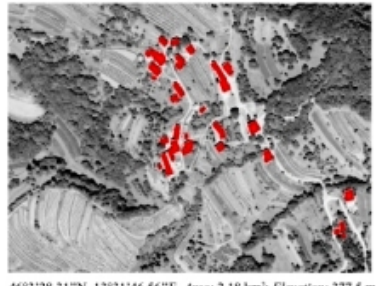

11 |GOLO BRDO_Upper Brda_H_C_IR_N_P_F

Characteristics: late Gothic church of St. Mary on the Lake, which is detached from the settlement; archaeological ceramic finds in the hill area,

Settlement typology_patterns: the original linear layout of the village situated on a ridge is expanded and complemented along the communication line, which is inconsistent with the continuous built-up settlement pattern,

Land use: mixed agricultural land in the plain - crops: peaches, potatoes, vines: forest (approx. $80 \% \mathrm{TSA}^{3}$ ); additional crops as home gardening - apples,

Agriculture: fragmented land plots in plain areas and along the stream, maximum utilisation of agricultural areas.

12 | KOŽ̌BANA_Upper Brda_H_L_IR_N_S_F

Characteristics: Gothic Church of St. George; in the past people made their livelihood from wood, livestock farming, and chestnut; a major proportion (approx. 70\%) of TSA is a Natura 2000 area, a part of TSA (approx. 25\%) is recognised as a natural asset - the Kožbanjšcek stream with its gorges ("Krěniki"), and pools,

Settlement typology patterns: the original linear layout of the village situated on a ridge, it remains in its original shape,

Land use: mixed agricultural land - potatoes, vines, wheat; meadows and forest (approx. 80\% TSA ); additional crops as home gardening apples; chestnut as a special forest crop,

Agriculture: fragmentation of agricultural land plots, partially as cultivated terraces (traditional); forest as a continuous whole.

13 BRDICE pri KOŽBANI_Upper Brda__H_L_IR_N_R_VF" Characteristics: secular architectural heritage - Italian school building from 1926; a large part of TSA (approx. $45 \%$ ) is a Natura 2000 area, a part of TSA (approx. $25 \%$ ) is recognised as a natural asset - the Kožbanjsček stream with its gorges ("Kréniki") and pools; presence of a gully,

Settlement typology_patterns: the original linear layout of the village situated on a ridge,

Land use: mixed agricultural land in cultivated terraces, potatoes, vines, wheat; meadows and forest (approx. $70 \% \mathrm{TSA}^{3}$ ); additional crops as home gardening - apples; chestnut as a special forest crop, Agriculture: fragmentation of agricultural land plots, partially as cultivated terraces (traditional); forest as a continuous whole.

\section{4 | SLAPNIK_Upper Brda_H_L_IR_N_S_VF}

Characteristics: a completely deserted village; protected as architectural heritage of the village as a whole; a large part of TSA (approx. 20\%) is a Natura 2000 area, part of TSA (approx. $45 \%$ ) is recognised as a natural asset - the Kožbanjơ̌cek stream with its gorges ("Kř̌niki"); part of TSA is an ecologically significant area - Korada, Kolovrat, Settlement typology_patterns: original linear layout of the village; deterioration,

Land use: mixed agricultural land - forest (approx. $80 \%$ TSA ${ }^{3}$ ); abandoned areas of vines and home gardening - apples (approx. 10\% TSA ${ }^{3}$ ); forest (approx. 80\% TSA $^{5}$ ); chestnut as a special forest crop; shrubs and herbs (approx. 10\% $\mathrm{TSA}^{3}$ ),

Agriculture: overgrown areas (approx. 10\% $\mathrm{TSA}^{3}$ ); forest.

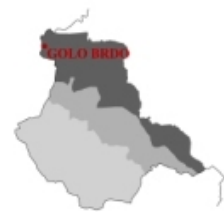

GOLO BRDO, First mecond: data not available.

Population: 21 inhabitants $(2015)^{2}$ Cadastral Municipality: 2277 Mimik

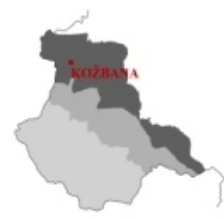

KOž̀ANA Firgu moond: 1353! Population: 37 inhabitants (2015) Cadastral Municipality: 2278 Kožbena

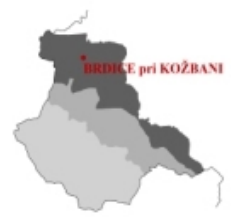

BRDICE pri KOŽBANI, Fïst recont: data not available

Population: 18 inhabitants $(2015)$ Cadastral Menicipaliny: 2278 Koæhana

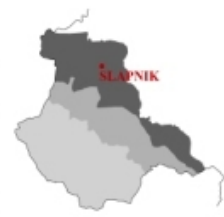

SLAPNIK, Fìns necond: data not available Population: 0 inhabitants (2015) Cadastrul Mrenicipulity: 2278 Ko:̌thens

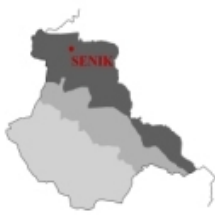

SENIK, First necond: data not availatie. Population: 23 inhabitants $(2015)^{2}$ Cadastral Municipalithy: 2277 Mimil

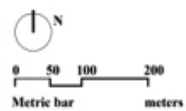

Characteristics: a Gothic Church of St. Magdalene; a reservoir from 1915 built by Italian soldiers for supply of soldiers and horses, composed of two subunits of hamlets and individual structures, and forest (approx. 70\% TSA $)$; additional crops as home gardening apples; chestnut as a special forest crop,

Agriculture: fragmentation of land plots in agricultural areas and cultivated terraces (traditional); overgrown areas (approx. $10 \% \mathrm{TSA}^{3}$ ) forest as a continuous whole.

Metrik bur Settement typology_patterns: original linear layout of the village,

' Kos, F., 1923, Goriska brda y srednjem veku. In: Stres, P. (ed.) et al., 1999. Briski zbornik. Dobrovo: obcina Brda, pp, 32-73.

${ }^{2}$ Statistical Office of the Republic of Slovenia, Ljubljana, SI-STAT, data from 1 January 2015. Accessed on 10 Sept. 2015 http:/pxweb.stat.si/pxweb/Dialog/varval.asp?ma-05C5002S\&ti-\&path-./Database/Dem_soe/05_prebivalstvo/10_stevilo_ preb/25_05C50_prebivalstvo_naselja/\&lang $=2$

'op. TSA - the total settlement area.

${ }^{4}$ Settlement patterns classification: pattern_form_layout_development stage_location in space_agrarian landscape. 


\section{RESULTS AND DISCUSSION}

Settlement forms and patterns are connected with the culture of a nation (historical and development framework), i.e. the living culture and the way of living (socio-economic framework [e.g. a well-organised living area adapted to the social structure of inhabitants, a sense of belonging, assimilation, etc.; appropriate building form with the use of natural, local materials, etc.]) and identity of individuals and the environment (cultural and aesthetic framework [e.g. harmony between landscape and settlement; conditions and scale adapted to people, etc.]) - all of this creates the context of a place.

The first direction in studying the basic form was concerned with the understanding of the organisation of the relationship between the individual patterns. Moreover, the understanding of the functional dynamics of a settlement is of key importance. The following is particularly important: many settlements consist of not one but several different layouts, and their composition is, in fact, a characteristic feature.

According to the classification system given in Table 1 , we tested the mix of the individual indicators for Goriška brda (e.g. descriptions in Figures 6a, 6b, 6c) affecting the connectivity with agricultural areas. We found that the basic settlement pattern that prevails in all three areas is the basic pattern which has been transformed from the village pattern as the composition of hamlets or isolated farmstead. In the Lower Brda, a hamlet is the basic composition unit of a village section through which the built structure dominates the overall SU area. This does not only relate to the form and morphology of the built structure, but mostly to the activities related to agriculture as an activity. A detailed pattern analysis reveals an image of Goriška brda that corresponds to the image of the agriculturally vital Lower Brda. Linear layout prevails in all three areas (i.e. position on a ridge). Interestingly, the most constrasts are found in the Lower Brda, i.e. between the desire to build (in mostly winegrowing areas, prone to landslides, or as cultivated terraces) and to shape new terraces and crops, i.e. expansion of agricultural land (Figure 3 - existing land use, deforestation, vineyard restoration, terrain gradients). Most settlement patterns still follow the irregular historical layout (original settlement). In terms of the evolution level of the settlement structures, the highest variability is identified in the Lower Brda a quarter of patterns is at the diffusion level, while others are in the form of dispersion, where an active approach to dealing with overall settlement areas is needed. The northern part of Brda is still at the nucleation stage, where in most patterns there is an indication of deterioration and abandonment of homesteads. In terms of the level of development, the understanding of space through the relationship between settlement patterns and multifunctional agriculture gives an image that is conflicting with the established trends of "densification" of settlements, as it follows the idea of "patterns with modern activities that foster connections at the level of the system". The latter confirms the "Nearest Neighbour Analysis" that helped us to establish that the Lower Brda settlement 
patterns intertwine with the landscape the most, i.e. overall SU areas. In terms of position in the landscape, we see the biggest intertwinement in the Lower Brda, where the settlement patterns pass from ridge positions to plain terraces. Based on the review of all these data related to the building in the individual SUs and the connectivity between them (i.e. the settlement pattern as a spatial unit creates the image of the landscape regardless of administrative boundaries) we assumed a general criterion valid in the Brda area, i.e. which crop most closely approximates the coverage of 70 percent of the SU area (in relation to the general land cover of Goriška brda), and what land area is covered by other crops (home gardening, olives, peaches, cherries, figs, etc.), excluding forests. In general, there are two completely different situations; the first category, approx. 70 percent area covered by vineyards, are all settlements in the Lower Brda (with the exception of the central settlement Dobrovo), while the Upper Brda area is also covered in 70 percent of uniform land cover - forests. A comparison of all these data and the restoration of vineyards and deforestation reveal a greater dynamics of land use change in the Central Brda. Notably, in all the individual SUs in Goriška brda, the laws of nature are still respected in relation to sensitive areas - terrain gradient, altitude and insolation.

\section{Discussion}

In this study, we drew the concepts from the fields of settlement patterns and their connection with the agrarian landscape to research the background of Goriška brda and its specific case of development, which has a strong connection with tradition. Goriška brda is an important study area because it contains many successful contemporary farms (mostly wineries) and traditionally includes innovative farming as landscape multifunctionality. Even though terrain diversity is, on the one hand, a major constraint that prevents intensity of agriculture, it shapes, on the other hand, the irreplaceable spatial scenario of landscape performance. The composition and patterns of many of the farms (with nonagrarian buildings) in the landscape of Brda reflect an agrarian cultural heritage demonstrating an unlimited harmony with nature. If we take a look at the large scale (panorama), we can define Goriška brda as a vineyard landscape. But if we zoom-in on the level of a single scenario (the level of a few lots), we can define this undulating landscape as a complex composition of different agrarian cultures which enrich the land, air and all human senses with everyday changes across all seasons. Do we need to introduce a new type of agrarian operations? We have to find a new balance between the highly developed Lower Brda and the Upper Brda that is losing its potential of a natural cultivated forest area. Through an analytical system of verifying the classification of settlement patterns we find that the balance passes from the lower part to the Central Brda area, whose agricultural areas currently undergo major changes.

\section{Study limitations}

The study shows that a good connectivity between the built structure and the agrarian space in a diversified terrain depends on the relationships between gradient, insolation, altitude, climate, bedrock, land use (also soil depletion, age 
of existing crops, impact of pests and chemical applications, etc.) that in the past allowed for dispersion of individual settlement patterns in the framework of SUs of a settlement. All these data are available, but some are too general and not defined at the metre accuracy (e.g. climate). On the other hand, information such as ownership, protection (settlement of Slapnik protected as a monument), cultural and sociological characteristics is important. In these detailed, hidden data we find the characteristics that affect the relationships in the same space. Example: various extremes are present, e.g. Medana (Lower Brda) with 238 inhabitants, SU area $1.3 \mathrm{~km} 2,88$ households, 4 major wine growers (overlap with winegrowers from the neighbouring Plešivo - 12 and Ceglo - 4) and Slapnik (Upper Brda) with 0 inhabitants and an SU area of $1.6 \mathrm{~km} 2$, with 0 households. These data demonstrate the pressures on agricultural land. Nevertheless, in a modern market-oriented agricultural holding, the latter is unpredictable, particularly in areas with intensive agricultural land. The high level of pressures on agricultural land is a direct indicator of the desire to develop the best agricultural land by building, i.e. for living in a settlement. The main limitation of this study is the fact that we cannot fully quantify the relationship between settlement patterns and the agrarian landscape to define the quality of system maintenance, but rather it is defined by the quality of living in a cultural and landscape system with all fine numerical, measurable, and particularly nonquantifiable indicators, such as human relations. The environment (space) is not something juxtaposed to man, or given or fixed beforehand, but rather it is continuously changed by humans, who grasp it in their own way, are equipped with new creations, and are inspired by their thoughts and feelings, while giving it a new structure (Trstenjak, 1984, 269). As Trstenjak (1992) wrote in his work Misli o slovenskem človeku ("Thoughts about Slovenes"): "The further south we go, the more human nature moves away from the average nature of Slovenes. The distinct Slovenian feature characteristic for all other Slovenes, i.e. more or less conservatism, is totally lacking. However, the people of the Goriška region are seen in a completely different light: their faces wear a friendly, naive openness with natural good cheer, which instantly captivates your heart." This unquantifiable indicator of the resident's nature in the agrarian landscape can be only indirectly linked to the diversity and openness of the Goriška brda cultural landscape towards south. This study can provide a challenge for further exploration of connectivity with the agrarian landscape, which was in this landscape observed as the openness of humans to the forms connected to multifunctional ecoagrarian systems, complemented by the hospitality of tourist farms. Indeed, the focus of this study was not to address the issues of land fragmentation, ownership and economic aspects of the changing agricultural holdings into market-oriented trade and agricultural complexes. The highlighted issue concerns the extent to which these "new opportunities" for shaping contemporary, larger farms as uniform complexes will change the "performance" of the whole Goriška brda landscape. 


\section{Future research}

The framework provided in this paper is just an initial step in understanding the potential in relation to the built area and the agrarian landscape, while developing an interdisciplinary approach to protect the value of agricultural systems, which is significant if the connection (also for tourists or daily visitors) exists. This research could help land owners and rural community planners to identify and adopt the settlement and landscape features that are defined in this study as "fragmentation and intertwinement on a small scale" with several added elements: cultural heritage, tourism and visual quality of the rural landscape.

\section{CONCLUSIONS}

Finally, the essential question is the following: Does the potential of the high level of connectivity between man and landscape lie in the winegrowing landscape? Can this knowledge of the significance of fine connectivity (i.e. of small settlement patterns with fragmented parcels and succession of crops) be used in the development of other crops? The perception of the landscape plays an important role, as this gives a priceless value to, and recognisability of, the producer, user of space, user of products or a random visitor.

\section{ACKNOWLEDGEMENTS}

This study was supported by the Scientific Research Programme of the University of Ljubljana, Faculty of Architecture. This research paper was made possible through the generous help and intellectual support from two researchers from the University of Ljubljana, Faculty of Architecture: Assist. Janez P. Grom and Assist. Miha Konjar (Figures 3, 6a, 6b, 6c; mapping and data).

\section{REFERENCES}

Antrop, M. (2005): Why landscapes of the past are important for the future. Landscape and Urban Planning. 70, pp. 21-34. doi: 10.1016/j.landurbplan.2003.10.002

Carey, P. D., Short, C., Morris, C., Hunt, J., Priscott, A., Davis, M., Finch, C., Curry, N., Little, W., Winter, M., Parkin, A. \& Firbank, L.G. (2003. The multi-disciplinary evaluation of a national agri-environment scheme. Journal of Environmental Management 69, pp. 71-91. doi:10.1016/S0301-4797(03)00120-8

Curovic, Z. \& Popovic, S. G. (2014): Typological classification of settlements in the rural hinterland of the bay of Boka Kotorska. Agriculture \& Forestry. 60, 4, pp. 275289. Internet Resource: http://www.agricultforest.ac.me/data/20141214034\%20Curovic\%20and\%20Popovic.pdf (accessed September 20, 2015).

Domon, G. (2011): Landscape as resource: consequences, challenges and opportunities for rural development. Landscape and Urban Planning, 100 (4), pp. 338-340. doi:10.1016/j.landurbplan.2011.02.014

European Commission (2012): The Common Agricultural Policy: A story to be continued. Luxembourg: Publications Office of the European Union. Internet Resource: http://ec.europa.eu/agriculture/50-years-of-cap (accessed September 17, 2015). 
Fikfak, A. (2008): Naselbinska kultura slovenskega podeželja - Goriška brda. Ljubljana: Univerza v Ljubljani, Fakulteta za arhitekturo.

Fridl, J., Kladnik, D., Orožen Adamič, M. \& Perko, D. (eds.) (1998): Geografski atlas Slovenije. Država v prostoru in času. Ljubljana: DZS.

Gabrijelčič, P., Fikfak, A. \& Čok, G. (2005): Management of settlements in the countryside - settlements without central significance. AR, 1, pp. 64-65.

Gude, P.H., Hansen, A.J., Rasker, R. \& Maxwell, B. (2006): Rates and drivers of rural residential development in the Greater Yellowstone. Landscape and Urban Planning, 77, pp. 131-151. doi:10.1016/j.landurbplan.2005.02.004

Jones, E. E. (2010): An analysis of factors influencing sixteenth and seventeenth century Haudenosaunee (Iroquois) settlement locations. Journal of Anthropological Archaeology, 29, pp. 1-14. doi:10.1016/j.jaa.2009.09.002

Kladnik, D. (1998): Goriška brda. Slovenija - pokrajina in ljudje. Ljubljana.

Kos F. (1923): Goriška brda v srednjem veku. Gorica: Jadranski almanah. Srebrnič M. 2009. KSS Brda. Internet Resource: http://www.kmetijskizavod-ng.si/ozavodu/oddelki/kmetijsko-svetovanje/kss-brda (accessed October 5, 2015).

Kutin Slatnar, B., Krajnc, A., Lojović Hadžihasanović, E. \& Stele, A. (2010): POPIS kmetijstva 2010 - vsaka kmetija šteje! Ljubljana: Statistični urad Republike Slovenije.

McHarg, I. (1969): Design with Nature. Natural History Press, Garden City, NY.

Milos B. \& Bensa A. (2014): A GIS based assessment of agricultural resources for karstic areas of the Adriatic coastal region. Agriculture \& Forestry, 60, 4, pp. 135- 141. Internet Resource: http://www.agricultforest.ac.me/data/20141214018\%20Milos\%20and\%20Bensa.pdf (accessed September 14, 2015).

Roberts, B. K. (1996): Landscapes of settlement - prehistory to the present. London: Routledge.

Robinson, P. S. (2003): Implications of rural settlement patterns for development: A historical case study in Qaukeni, Eastern Cape, South Africa. Development Southern Africa, 20, 3, pp. 405-421.

Taylor Lovell, S., DeSantis, S., Nathan, C. A., Breton Olson, M., Méndez, V. E., Kominami, H. C., Erickson, S. L., Morris, K. S. \& Morris, W. B. (2010): Integrating agroecology and landscape multifunctionality in Vermont: An evolving framework to evaluate the design of agroecosystems. Agricultural Systems, 103, pp. 327-341. doi:10.1016/j.agsy.2010.03.003

Tempesta, T. (2010): The perception of agrarian historical landscapes: A study of the Veneto plain in Italy. Landscape and Urban Planning 97, pp. 258-272. doi:10.1016/j.landurbplan.2010.06.010

Trstenjak, A. (1984): Ekološka psihologija: problemi in perspektive. Ljubljana: Gospodarski vestnik.

Trstenjak, A. (1992): Misli o slovenskem človeku. Ljubljana: Mihelač.

Vrišer, I. (1956): Morfološki razvoj v Goriških brdih. Geografski zbornik 4. Ljubljana.

Waugh, D. (1990): Geography - an integrated approach. Nelson: Walton-on-Thames [etc.]. 1st publ.

Žnidar, I. (2015): Geografski vidiki vinogradništva v vinorodnem okolišu Goriška brda in vinorodnem ožjem okolišu Hmeljčič-Trška gora. Zaključna seminarska naloga. Ljubljana: Univerza v Ljubljani, Filozofska fakulteta, oddelek za geografijo. Internet $\quad$ Resource: http://geo.ff.unilj.si/pisnadela/pdfs/zaksem_201509_iris_znidar.pdf (accessed October 27, 2015). 